Ks. Rafał Szczurowski

Uniwersytet Papieski Jana Pawła II w Krakowie

\title{
Oświecenie i kontroświecenie czasów Królestwa Polskiego. Polemika o. Karola Surowieckiego z ministrem Stanisławem Kostką Potockim
}

W XVIII w. oświecenie stało się wiodącym poglądem i miarą postaw życiowych. Protagoniści tego nurtu umysłowego odrzucali obciążenia przeszłości i skupiali się na człowieku samodzielnie myślącym, kształtującym proces dziejowy. Bezkompromisowo, nie zważając na skutki, racjonalnej krytyce poddawali otaczającą ich rzeczywistość - systemy myślowe, zastały porządek społeczny i polityczny, poglądy na temat świata immanentnego i transcendentnego, naukę i religię, traktowaną na równi z innymi zjawiskami społecznymi. Promując deizm, chrześcijaństwo zrównywali z religią naturalną, systemem etycznym uznającym Najwyższą Istotę, który podważał fundamentalną dla chrześcijaństwa zasadę żywej relacji z osobowym Bogiem. Zawłaszczając edukację i kształtowanie obywateli, dążyli do poszerzenia dominacji państwa nad Kościołami i sferą religii. W rezultacie w oświeceniu dokonał się gruntowny przewrót we wszystkich dziedzinach. Był on radykalniejszy od wcześniejszych usiłowań zmierzających do wyswobodzenia ludzi spod panowania historii, osłabiających podstawowe wartości tradycji. Nie wszędzie jednak przebiegał tak samo, co sprawiało, iż ów przewrót miał także umiarkowaną wersję.

W katolickich krajach niemieckich w drugiej połowie XVIII i na początku XIX stulecia według tej wersji odnawiano życie kościelne. Wykorzystując zdrowe elementy oświecenia oraz odwołując się do Ewangelii i przepisów kościelnych, promotorzy przemian reformowali teologię, 
duszpasterstwo, liturgię, działalność charytatywną, pobożność. Pragnęli dostosować zastaną rzeczywistość do nowych czasów, a zarazem mobilizować współwyznawców do odkrywania istoty chrześcijaństwa ${ }^{1}$.

W Rzeczpospolitej rozkwit formacji kulturowej odwołującej się do siły ludzkiego rozumu nastąpił w czasach stanisławowskich. Wtedy to ukształtowała się specyfika polskiego wieku świateł², na którą katolicyzm miał znaczący wpływ. Jego oświeceni przedstawiciele, powołując się na idee nowej epoki i zasady ewangeliczne, podjęli reformatorski wysiłek (czerpiąc z wzorców zagranicznych ${ }^{3}$ ), który był nastawiony na zharmonizowanie potrzeb doczesnych i wiecznych wspólnoty wierzących. Dlatego też w obszarze sacrum większą rangę zdobywała racjonalność, wyznacznikiem kościelnej aktywności stawał się utylitaryzm, na znaczeniu zyskiwał ewangeliczny humanitaryzm, oświeceniowy optymizm pobudzał do tworzenia idealnych wzorców postaw religijnych, przekształceniu ulegała barokowa pobożność ${ }^{4}$.

Oświeceniowe przeobrażenia nie cieszyły się jednak powszechną akceptacją katolików. W opozycji do owych przemian rozwijał się nurt kontroświecenia, który przybrał na sile w wyniku antykościelnej i antyreligijnej polityki francuskich rewolucjonistów. Zwolenników tego nurtu łączyło podobne postrzeganie wieku świateł jako kresu starego świata i jego

1. Zob. R. Butterwick, Co to jest oświecenie?, "Przegląd Powszechny" 921 (1998) nr 5, s. 161-180; S. Janeczek, Oświecenie chrześcijańskie. Z dziejów polskiej kultury filozoficznej, Lublin 1994; J. Kracik, Ewangelicznie i rozumnie. Oświecenie katolickie, "Znak" 44 (1992) nr 451, s. 57-69; G. Schweiger, Oświecenie a katolicyzm, "Concilium" 1966-1967, s. 73-82; F. Valjavec, Geschichte der abendländischen Aufklärung, Wien-München 1961.

2. Por. T. Kostkiewiczowa, Polski wiek świateł. Obszary swoistości, Wrocław 2002.

3. Współcześni badacze, spierając się ze sobą, źródeł oświeceniowych reform w Kościele polskim doszukują się w całej gamie ówczesnych zachodnioeuropejskich nurtów myślowych i systemów - jansenizmie i gallikanizmie (T. Cegielski, Jansenizm i gallikanizm w polskim Oświeceniu. Badania - opinie - postulaty, w: W stronę Francji... Z problemów literatury i kultury polskiego Oświecenia, red. E. Z. Wichrowska, Warszawa 2007, s. 71-88), febronianizmie i józefinizmie (K. Karaskiewicz, Wpływ idei niemieckiego oświecenia na edukacyjna działalność prymasa Michała Poniatowskiego. Fascynacje i kontakty, "Mazowieckie Studia Humanistyczne" 5 (1999) nr 1, s. 67-91; M. Skrzypek, Józefinizm w polskim oświeceniu, "Przegląd Humanistyczny" 38 (1994) z. 2, s. 41-56) czy libertynizmie (J. Snopek, Oświecenie. Szkice do portretu epoki, Warszawa 1999, s. 32; J. Snopek, Objawienie i Oświecenie. Z dziejów libertynizmu w Polsce, Wrocław 1986, s. 242).

4. Zob. R. Szczurowski, "Zaradzić potrzebom doczesnym i wiecznym". Idee oświecenia w Kościele katolickim w Polsce (do 1795 r.), Kraków 2014. 
porządku. W tym, w czym ich ideowi przeciwnicy dostrzegali postęp, oni widzieli zaprzeczenie niegdysiejszego ładu. Występując z pozycji apologetów chrześcijaństwa, ostrzegali więc przed chaosem, upadkiem norm moralnych i życia wspólnotowego. Kontestowali oświecenie z jego założeniami i przejawami, krytycznie oceniając nowoczesność.

W Polsce początki kontroświecenia przypadają na czas reform państwa przeprowadzanych za panowania Stanisława Augusta przy użyciu idei oświeceniowych. Wówczas to przeciwnicy tych idei skupiali się na obronie fundamentalnych zasad katolicyzmu, w ich przekonaniu podważanych, by po 1789 r. skoncentrować się na łączeniu francuskiego rewolucyjnego przewrotu z oświeceniem oraz zwalczaniu nowej filozofii. W schyłkowej fazie epoki rozumu rodzimi antyoświeceniowcy polemikę z ideowymi przeciwnikami zawęzili do zagadnień ściśle religijnych, reagując na zjawisko narastającej laicyzacji. Dlatego też w dobie Królestwa Polskiego wywodzący się w większości z drobnej i średniej szlachty adwersarze oświecenia żywili nadzieje na odrodzenie starych wartości. Zaprowadzany po kongresie wiedeńskim ład w Europie - restauracja starego porządku - stwarzał ku temu dogodne warunki. Krajowi kontroświeceniowcy będą więc występować przeciw wprowadzanym innowacjom w relacjach państwo-Kościół. Podejmą działania wzmacniające pobożność i duchowość. Nakreślą nowe wzorce religijności i wychowawcze. Podejmą się rehabilitacji papiestwa. Protestować będą przeciw przejawom etatyzacji Kościoła. Wytrwali pozostaną w zwalczaniu osiemnastowiecznej filozofii oraz tego wszystkiego, co uznawali za szkodliwe dla współczesności i religii5.

Do tego grona należał o. Karol Surowiecki, nieprzejednany antagonista oświeceniowych tendencji. W swoich polemikach gwałtownie występował przeciwko nim i ich zwolennikom, m.in. ministrowi Stanisławowi Kostce Potockiemu, który podjął z Surowieckim dyskurs. Ich słowne starcia stanowiły wręcz modelowy przykład zmagań reprezentantów przeciwstawnych formacji ideowych - oświecenia i kontroświecenia - wzajemnie się zwalczających.

5. Zob. M. Deszczyńska, Polskie kontroświecenie, Warszawa 2011, s. 185-252; por. R. Butterwick, Between Anti-Enlightenment and enlightened Catholicism: provincial preachers in late eighteenth-century Poland-Lithuania, w: Perepheries of the Enlightenment, ed. R. Butterwick, S. Davis, G. Sanchez Espinoza, Oxford 2008, s. 201-208 (Studies on Voltaire and the Eighteenth Century, 1); R. Butterwick, Polska rewolucja a Kościół katolicki 1788-1792, Kraków 2012, s. 171-173, 325-329.

Ks. Rafał Szczurowski, Oświecenie i kontroświecenie... 
Karol Surowiecki, urodzony w 1750 lub 1754 r. w Imielniku koło Gniezna, pochodził z rodziny drobnoszlacheckiej. W $1769 \mathrm{r}$. wstąpił do Zakonu Braci Mniejszych Konwentualnych prowincji polskiej, gdzie około 1776 r. przyjął święcenia kapłańskie. Po kilku latach zmienił jednak przynależność zakonną, na co miała wpłynąć przegrana w dyspucie zorganizowanej w 1785 r. w Kaliszu przez franciszkanów-reformatów. Surowiecki, wówczas lektor filozofii, uznawszy wyższość swoich interlokutorów, postanowił do nich przystać. Przeszedł do Wielkopolskiej Prowincji Reformatów pw. św. Antoniego z Padwy ${ }^{6}$. W nowo obranym zakonie w 1787 r. złożył śluby, po czym na powrót trafił do Kalisza, obejmując w tamtejszym kościele reformackim funkcję kaznodziei dla katolików narodowości niemieckiej. Rok później był już kaznodzieją w warszawskim kościele św. Antoniego Padewskiego, gdzie z ambony z ogromną pasją zwalczał adherentów oświecenia, masonów i wszelkiego rodzaju przeciwników religii. Ostrość tych wypowiedzi spowodowała, że 26 marca 1789 r. oficjał warszawski na miesiąc zakazał Surowieckiemu głoszenia kazań. Kara nie wpłynęła jednak na zmianę postawy kaznodziei. Wręcz przeciwnie, jeszcze usztywnił swoje stanowisko. Z kazalnicy i w pismach polemicznych nie ustawał w piętnowaniu filozofizmu, który rozumiał jako negację lub kwestionowanie chrześcijaństwa i religii objawionej. Ustawy Sejmu Wielkiego skojarzył więc z rewolucja francuską, którą postrzegał jako zło rozlewające się po całej Europie i punkt zwrotny $\mathrm{w}$ dziejach ${ }^{7}$. Postulował zniesienie tajnych towarzystw, podporządkowanie oświaty Kościołowi, przywrócenie jezuitów i inkwizycji. Na dodatek te poglądy o. Surowiecki prezentował w sposób nieustępliwy i gwałtowny, przez co rosły zastępy jego oponentów. Dlatego też władze prowincji zakonnej, prawdopodobnie pod koniec 1792 r., zabroniły żarliwemu polemiście wygłaszania kazań, a w 1793 r. przeniesiony został z Warszawy do klasztoru w Lutomiersku, gdzie objął funkcję gwardiana. W roku

6. Zdaniem Michała Nowodworskiego - pierwszego biografa prezentowanego zakonnika - dokonana przez Surowieckiego zamiana franciszkanów konwentualnych na reformatów spowodowana była nie przegraną dysputą, ale stanowiła wynik poszukiwań duchowych, tj. zafascynowania surowością reguły reformatów. Zob. M. Nowodworski, Ksiądz Karol Surowiecki, Warszawa 1870, s. 12-13.

7. W kwietniu 1792 r. Surowiecki chciał czytać z ambony list jednego z biskupów francuskich potępiających rewolucję, na co protestem zareagował obecny w kościele warszawskich reformatów działacz Kuźnicy Kołłątajowskiej Kazimierz Konopka. Zob. A. J. Szteinke, Kościół świętego Antoniego i klasztor Franciszkanów-Reformatów w Warszawie 1623-1987, Kraków 1990, s. 223-224. 
następnym (do 1796 r.) był znowu w Kaliszu jako kaznodzieja w kolegiacie św. Józefa. I choć w zakonie pełnił jeszcze różne funkcje, np. w 1821 r. wizytatora generalnego Małopolskiej Prowincji Reformatów pw. Matki Bożej Anielskiej, walki z admiratorami oświecenia nie zaprzestał ${ }^{8}$.

W polemicznym zapale Surowiecki nie stronił w swoich pismach od niewybrednych metafor oraz budzącego zgorszenie i niesmak słownictwa, zwracając się przeciw rozpoznanym wrogom ${ }^{9}$. Bronił przed nimi Kościół i religię, ale - jak oceniał historyk zakonu reformatów o. Anzelm Szteinke - jego dzieła „na skutek niepohamowanej gwałtowności wystąpień autora w gruncie rzeczy więcej szkodziły samej sprawie, aniżeli pomagały. Widać u Surowieckiego wyraźne uwstecznienie poglądów. O ile bowiem w książkach wydanych w 1792 r. gotów był uznać pewne pozytywy rewolucji francuskiej, o tyle w latach po 1812 r. - pod wpływem opowiadań emigrantów francuskich, a zwłaszcza lektury dzieła Augustina Barruela - potępił jakiekolwiek zmiany i postulował powrót do stosunków sprzed 1789 roku"10.

Przeciwieństwem antyoświeceniowo nastawionego reformata, a zarazem jego adwersarzem był Stanisław Kostka Potocki. Urodzony w 1755 r. w Lublinie, pochodził z możnego rodu. Wykształcenie zdobywał u warszawskich pijarów i za granicą. W 1778 r. rozpoczął działalność publiczną, pozostając w kręgu polityki Czartoryskich. W okresie Sejmu Wielkiego był jednym z najaktywniejszych posłów. Wspierał linię polityki swego brata Ignacego. Brał udział w pracach ustawodawczych sejmu. Należał do tych, którzy doprowadzili do uchwalenia Konstytucji 3 Maja. Najaktywniejszy

8. Zob. A. J. Szteinke, Surowiecki Karol, w: Polski Słownik Biograficzny [dalej: PSB], t. 46, Warszawa-Kraków 2009-2010, s. 9-12; A. J. Szteinke, Surowiecki Karol, w: Słownik Polskich Teologów Katolickich, red. H. E. Wyczawski, t. 4, Warszawa 1983, s. 226-228.

9. Poddając analizie język, argumentację i zastosowane środki w antyoświeceniowej twórczości o. Surowieckiego, Martyna Deszczyńska dowodziła że reformat nie był erudytą, ale sarmackim z ducha polemistą. Do polemik jednak solidnie się przygotowywał - korzystał z Pisma Świętego, Ojców Kościoła, literatury teologicznej i filozoficznej, prasy. Jego prace adresowane do przeciętnie wykształconego odbiorcy mieściły się w konwencji osiemnastowiecznych utworów refutacyjnych. Prezentowane zaś w nich poglądy były charakterystyczne dla tradycjonalistycznej, niechętnej oświeceniu części społeczeństwa. Zob. M. Deszczyńska, Styl, gust, realia. O publicystyce ks. Karola Surowieckiego, w: Non cesso gratias agere Deo et hominibus. Prace ofiarowane Ojcu dr. Anzelmowi Januszowi Szteinke OFM z okazji Złotego Jubileuszu Kapłaństwa i ponad 5o-lecia pracy historyczno-pisarskiej, red. W. M. Michalczyk, C. M. Pankowski, Kraków-Warszawa 2013, s. 483-484.

10. A. J. Szteinke, Kościół..., dz. cyt., s. 266.

Ks. Rafał Szczurowski, Oświecenie i kontroświecenie... 
politycznie czas w życiu Potockiego miał jednak dopiero nastać. Stało się to w okresie Księstwa Warszawskiego, kiedy łączył stanowiska prezesa rządu, kierownika oświaty i przełożonego loży masońskiej jako Wielki Mistrz Wielkiego Wschodu Narodowego ${ }^{11}$. W latach 1808-1814 był także komendantem Korpusu Kadetów. Współpracował z warszawskim Towarzystwem Przyjaciół Nauk.

Po upadku Księstwa Warszawskiego i powstaniu Królestwa Polskiego, połączonego z Rosją, której car stał się równocześnie królem Polski, Potocki objął kierownictwo Komisji Rządowej Wyznań Religijnych i Oświecenia Publicznego, a w 1818 r. został prezesem senatu. Pomimo tych stanowisk jego pozycja polityczna słabła. Nie rozumiał zachodzących zmian. Nie dość świadom antyliberalnej polityki Aleksandra I w rzeczywistości w niej uczestniczył. Wspólnie ze Stanisławem Staszicem przyczynił się do zaprowadzenia w królestwie cenzury. Obniżała się też jego ranga wśród wolnomularzy. W wyniku sporu wokół struktury organizacyjnej Wielkiego Wschodu, który doprowadził do rozłamu w obediencji polskiej, Potocki 3 marca $1821 \mathrm{r}$. zrzekł się funkcji wielkiego mistrza ${ }^{12}$.

W działalności ministra Potockiego zawsze ważne miejsce zajmowała kwestia edukacji. Troszcząc się o oświecenie publiczne w Królestwie Polskim, kontynuował prace rozpoczęte w Księstwie Warszawskim. Rozbudował sieć szkół. Wprowadził spójny system kształcenia w szkołach średnich. Zamierzał wprowadzić powszechne nauczanie dla dzieci. Za jego rządów w oświacie pomyślnie rozwijało się szkolnictwo zawodowe ${ }^{13}$.

11. W długiej wolnomularskiej karierze Stanisław Kostka Potocki był zaangażowany w życie lóż masońskich takich jak: Rycerze Gwiazdy, Bracia Zjednoczeni, Świątynia Izis, Kazimierz Wielki, Świątynia Równości, Pochodnia Północy, Przyjaciele Ludzkości. Zob. B. Grochulska, Potocki Stanisław Kostka, w: PSB, t. 28, WrocławWarszawa-Kraków-Gdańsk-Łódź 1984-1985, s. 166; W. Smoleński, Przewrót umysłowy w Polsce wieku XVIII. Studia historyczne, oprac. i wstęp A. Wierzbicki, Warszawa 1979, s. 211, 216-217, 225.

12. Zob. L. Hass, Sekta farmazonii warszawskiej. Pierwsze stulecie wolnomularstwa w Warszawie (1721-1821), Warszawa 1980, s. 456-475; B. Grochulska, Potocki..., dz. cyt., s. 166.

13. Organizując szkolnictwo w Księstwie Warszawskim i Królestwie Polskim, Stanisław Kostka Potocki i jego współpracownicy w sensie ideowym nawiązywali do dziedzictwa Komisji Edukacji Narodowej. Stworzyli nowoczesny system edukacji, u podstaw którego legły zasady: powszechnej dostępności do oświaty, świeckości, tj. zależności od państwa, jednolitości oraz drożności umożliwiającej uczniom przechodzenie na kolejne stopnie kształcenia. Zob. A. Winiarz, Szkolnictwo Księstwa Warszawskiego i Królestwa Polskiego (18o7-1831), Lublin 2002, s. 521-523. 
Twórczość literacką Potocki rozpoczął późno, w wieku dojrzałym, posiadając już bagaż życiowych doświadczeń. W swoich pracach skupiał się na badaniach nad językiem i literatura polską, na krytyce literackiej i teatralnej, na teorii literatury. Pisał też utwory obyczajowe i satyryczne. Podjął współpracę z „Pamiętnikiem Warszawskim”. Na jego łamach pod pseudonimem „Świstek"14 publikował artykuły w rubryce "Świstek Krytyczny". Poddawał w nich krytycznemu rozbiorowi różnoraką twórczość literacką, wzorując się na francuskim czasopiśmie "Żółty Karzeł", którego ostrze satyry było wymierzone w reakcję polityczną we Francji ${ }^{15}$.

Ukształtowany przez idee oświecenia i działający według założeń doby racjonalizmu minister-literat był symbolem trwałości urządzeń i tradycji Sejmu Czteroletniego. Politycznie jednak ten liberalizujący arystokrata, wolterianin i sceptyk rozmijał się coraz bardziej z młodym pokoleniem, wrażliwym na swobody obywatelskie, tożsamość narodową, niegodzącym się z systemem władzy zafundowany królestwu przez Aleksandra I i jego popleczników. Konserwatyści krytykowali go za podporządkowanie duchowieństwa państwu. Kościół bowiem, zgodnie z oświeceniowymi schematami, Potocki postrzegał jako jeden z elementów sprawnie funkcjonującej machiny państwa. Natomiast w życiu osobistym ministra cechowały sprzeczności - pyszny jak przystało na Potockich, porywczy, skłonny do hipochondrii i zmiennych nastrojów, małostkowy, a jednocześnie

14. Ze swojego pseudonimu Potocki tłumaczył się w następujący sposób: „Kiedy szanowni towarzysze moi przybierają sobie nazwiska sławnych dzienników paryskich, ja na skromnym Krytycznego Świstka pozostaję. [...] gdybym sobie nadał tak zawołane Karła Żółtego imię, słusznie by po mnie oczekiwała publiczność choć cząstki jego dowcipu. Otóż sęk, otóż trudność, otóż bieda. Wiele przyrzekłszy publiczności, a dotrzymać mało w stanie, przeskakiwałbym z wstępu na wstęp i jeszcze nowym wstępem starałbym się wykręcić, gadałbym wiele o sobie, mało o rzeczach, obiecawszy krytykować, inszych krytykować uczyłbym, na koniec znudzony czytelnik przed wieczornym gadulstwem moim rzekłby: niezgrabny karle, cóż masz wspólnego z tym przyjemnym karzełkiem, który tak długo bawi Paryż cały, prócz imienia, któreś sobie bezczelnie przywłaszczył? Wolę tedy być Świstkiem i na zawsze Świstkiem niż kiedykolwiek podobnej popaść wymówce". Cyt. za S. K. Potocki, Podróż do Ciemnogrodu i Świstek Krytyczny, oprac. E. Kipa, Wrocław 1955, s. XXVI-XXVII. O satyrycznej twórczości Potockiego w epoce stanisławowskiej zob. W. Woźniakowski, Pamflet obyczajowy w czasach Stanisława Augusta, Wrocław-Warszawa-Kraków-Gdańsk 1973, s. 141-145.

15. "Le Nain Jaune" (Żółty Karzeł) redagowany w latach 1814-1815 przez Louis Cauchois-Lemaire'a sprzeciwiał się porządkowi ustalonemu na kongresie wiedeńskim. Piętnował zwolenników powrotu ancien regime'u, ale króla i religii nie zwalczał. Zob. S. K. Potocki, Podróż..., dz. cyt., s. XLIII, XLIX-LI. 
prostolinijny w kontaktach z ludźmi, spokojny i taktowny, wielkoduszny w pracach na rzecz społeczeństwa i działalności publicznej, w życiu rodzinnym wierny mąż i kochający ojciec. Będąc estetą, dbał o ład i piękno ${ }^{16}$.

Niewątpliwie nurt konserwatywny swymi pismami zasilał K. Surowiecki, w tym polemiką z ministrem Potockim. Do ich bezpośredniego starcia doszło po raz pierwszy w 1818 r. Był to czas negocjacji konkordatu ze Stolicą Apostolską (przełom 1816 i 1817 r.) oraz przygotowania rozporządzeń do wydanego w marcu 1817 r. dekretu regulującego sytuację duchowieństwa w Królestwie Kongresowym. Kler zabiegał wówczas o korzystne dla siebie ułożenie relacji z władzami ${ }^{17}$. Poza tym na pierwszym sejmie Królestwa w 1818 r. została złożona do laski marszałkowskiej petycja dotycząca „oddalenia Żydów z karczem i onym wzbronienia szynkowania wódki"18. Współbrzmiała ona z projektami polityków postulującymi zmiany w funkcjonowaniu społeczności żydowskiej. Te dały o. Surowieckiemu dogodny pretekst, by zaatakować po raz kolejny ideowych przeciwników. W broszurze Głos ludu izraelskiego do prawdziwych chrześcijan polskich, przeciw fałszywym ich politykom z okazyi projektów ku zgubie tegoż ludu rozrzuconych między stany sejmujace $w$ Warszawie, udając reprezentanta religii mojżeszowej, rozprawiał się z pomysłami asymilacji Żydów oraz usunięcia ich z Królestwa Polskiego. Zarzucał zgromadzonym w stolicy parlamentarzystom chęć ustanowienia prawa przeciwnego Bogu, Ewangelii i Izraelitom. Jego pomysłodawcy "to tajemnicza banda zdrajców ludzkiego rodzaju - orzekał Surowiecki - która dziś zarzuciwszy nazbyt spospolitowane massonów, illuminatów, jakobinów nazwiska, pod maską chlubnego filozofów, mędrców, literatów i polityków imieniem podszywa swe zbrodniarskie kabały"19. Zamiarem ich było usuwanie tego, co odróżniało od siebie narody, promowanie liberalnej oświaty, uwalnianie od przesądów, obdarowywanie równością, wolnością i niezależnością. Dlatego też Żydów

16. Zob. B. Grochulska, Potocki..., dz. cyt., s. 167-168; Zob. B. Grochulska, , Dramat liberała, w: Losy Polaków w XIX-XX w. Studia ofiarowane Profesorowi Stefanowi Kieniewiczowi w osiemdziesiąta rocznice Jego urodzin, red. B, Grochulska, J. Skowronek, Warszawa 1987, s. 137-149.

17. Zob. M. Deszczyńska, Styl..., dz. cyt., s. 473.

18. Zob. Diariusz Sejmu Królestwa Polskiego 1818, t. 3, Warszawa [b. r.], s. 92.

19. [K. Surowiecki], Głos ludu izraelskiego do prawdziwych chrześcijan polskich, przeciw fałszywym ich politykom, z okazyi projektów ku zgubie tegoż ludu rozrzuconych między stany sejmujące w Warszawie. Przez Rabbi ben Abrahama duchownego synagogi Ł. R. Ery chrześcijańskiej 1818, [b. m. r.], s. 10. 
zamieszkujących Kongresówkę planowali pozbawić języka, obyczajów, sądownictwa, prawa małżeńskiego, a więc odmienić ich tożsamość i w ten sposób wydać na łatwy łup areligijności oraz nowej filozofii. Przez nadanie praw i przywilejów obywatelskich usiłowali wyzuć Izraelitów z narodowej i religijnej odrębności.

Oprócz tego piewcy oświeconych przemian, w ocenie autora Głosu ludu izraelskiego, wykazywali się wobec Żydów bezwzględnością i przewrotnością. Proponowali bowiem deportować wyznawców religii mojżeszowej „na granice Tartaryi" oraz przedstawiali ich opinii publicznej jako sprzymierzeńców masonów, iluminatów, jakobinów. Nadto posługiwali się dobrze znanymi oskarżeniami o rozpijanie i demoralizację pospólstwa, o chciwość i próżniactwo. A przecież, jak wyjaśniał Surowiecki, wina leżała po stronie szlachty dzierżawiącej karczmy Żydom. Ci, aby się utrzymać oraz wypłacić panom, zmuszeni byli uciekać się do różnych oszukańczych praktyk. Dużym nakładem sił i środków prowadzili interes. „Gdyby chrześcijaninowi z równemi warunkami narzucono szynkownią - przewidywał reformat-polemista - pewno przy swoim kosztowniejszym życiu, a mniejszym obrocie daleko gorzej nad Żyda zaszargałby sumienie, chcąc uniknąć bankructwa"20. Autor Głosu ludu izraelskiego zaprzeczał też oskarżeniom, jakoby chciwość kierowała Żydami oraz że byli próżniakami, bo nie pracowali na roli. To, iż gorliwiej niż chrześcijanie zabiegali o pomnożenie kapitału, wynikało z obowiązku płacenia większych podatków. Nie zajmowali się rolnictwem, ale się nie lenili. Wyspecjalizowali się bowiem w handlu i rzemiośle ${ }^{21}$.

W broszurze o. Surowiecki przekonywał również, że Żydzi nie byli zdrajcami Polski sprzymierzającymi się z jej wrogami. Ich sytuację w kraju porównywał do biblijnych czasów niewoli egipskiej. Przypominał zarazem, że naród żydowski dzięki Bożej Opatrzności przetrwał wiele trudnych doświadczeń. Był więc pewny, iż promotorzy oświeceniowych zasad, którzy nastawali na tożsamość tego narodu albo snuli plany jego deportacji, walczyli z samym Bogiem. I walkę tę przegrać musieli. Na zakończenie autor Głosu ludu izraelskiego zamieścił prośbę skierowaną do Aleksandra I, jako nowego Cyrusa, o łaskę sprawiedliwości. „Spojrzyj ze szczytu swego

20. [K. Surowiecki], Głos ludu..., dz. cyt., s. 35 .

21. [K. Surowiecki], Głos ludu..., dz. cyt., s. 36. Pomysły osadzenia Żydów na roli bez wsparcia państwa, a z nałożeniem obciążeń pańszczyźnianych uważał Surowiecki za szkodliwe dla gospodarki. 
majestatu na biedny stan izraelskiego plemienia - pisał reformacki zakonnik - a zawstydzając nadzieje jego zawziętych nieprzyjaciół, zemściej się attentowanej przez nich zniewagi twojego ubłogosławionego imienia"22.

W reakcji na ten głos minister Potocki opublikował tekst zatytułowany Żyd nie Żyd? Odpowiedź na głos ludu izraelskiego. Dowodził w nim, że autor broszury broniącej Żydów sam nie był Żydem, a stan, w jakim naród żydowski się znajdował, został spowodowany nie zemstą dobrego Boga, ale winą tegoż narodu - sami się „wygnali z Kościoła Bożego, przywiązani do zabobonów swoich, a wzdragający się czystej moralności Chrystusa"23. Minister tłumaczył, iż Żydzi w cywilizowanych krajach byli tolerowani, a projekty rządów nie dążyły do obalenia ich wiary, ale uczynienia z nich „współobywateli i braci". Nie dostrzegał więc nic niewłaściwego w obserwowaniu przez władze państw rozwoju demograficznego wyznawców judaizmu, dwukrotnie większego niż chrześcijan (zwłaszcza na ziemiach polskich), ani w pomyśle ich przesiedlenia. Zauważał też, że autor Głosu ludu izraelskiego lud ten traktował przedmiotowo. Ujmował się za nim nie przez swoją do niego atencję, "lecz przez wściekłość ku nieprzyjaciołom swoim, których pod pozorem obrony Żydów, rad by na ich miejscu wśród gorejących stosów postawić"24. Przez to, w ocenie Potockiego, okazał się kiepskim Polakiem, bo nie zauważał szkód, które Żydzi przynosić mieli ojczyźnie ${ }^{25}$. W jej zaś żywotnym interesie, w przeświadczeniu ministra, leżało zreformowanie Izraelitów - wydobycie z motywowanych religią postaw wrogości do nie-Żydów czy aspołecznego postępowania. Skutecznym remedium miała być oświata.

W tych poglądach minister odpowiedzialny za edukację w Kongresówce okazywał się w całej krasie spadkobiercą zarówno starych uprzedzeń i mitów, jak i oświeceniowego podejścia do społeczności żydowskiej.

22. [K. Surowiecki], Głos ludu..., dz. cyt., s. 48.

23. [S. K. Potocki], Żyd nie Żyd? Odpowiedź na głos ludu izraelskiego, [b. m. r.], s. 9.

24. [S. K. Potocki], Żyd nie Żyd? ..., dz. cyt., s. 20.

25. Stanisław Kostka Potocki postrzegał Żydów w Królestwie jako zło konieczne. Realistycznie przewidywał, że usunięcie ich, przy słabym rodzimym mieszczaństwie, wywołałoby w kraju gospodarcze załamanie. Godził się więc na Żydów handlarzy, lecz już pobyt na wsi przedstawicieli wyznania mojżeszowego uważał za niepożądany. „Tam to oni żyją w próżniactwie - argumentował minister - szkodliwe pijawki ssą krew ludu naszego, tam to ich przewrotny dowcip jedynie ku oszukaniu natężony, o pijaństwo i ostateczną nędzę lud nasz wiejski przyprawia", pozbawia owoców pracy, tamuje oświatę, bo nieoświecenie włościan „jest największym Żydów dobrem". [S. K. Potocki], Żyd nie Żyd?..., dz. cyt., s. 22. 
To w reformowanej Rzeczpospolitej obok nierealistycznych pomysłów usunięcia Żydów z kraju czy ograniczenia im możliwości wyboru miejsca zamieszkania ujawniły się głosy podnoszące problem traktowania wyznawców judaizmu na równi z innymi warstwami społecznymi, otwarcie opisujące ich rzeczywistą sytuację, wreszcie wyrażające dążenia asymilacyjne, tj. włączenia do zunifikowanej społeczności modernizowanego $\mathrm{kraju}^{26}$. Za tymi głosami szło też postępowanie. Uchwalając Konstytucję 3 Maja, oświeceni reformatorzy wstępowali na drogę, "na której końcu jak zauważał Janusz Tazbir - leży nadal państwo katolickie, ale w pełni niezawisłe od Kościoła, oparte na zasadach tolerancji, lecz starające się zmniejszyć liczbę wyznawców prawosławia, dążące do oświecenia wszystkich obywateli, ale za pośrednictwem jednego tylko języka, jakim miała się stać wszechwładnie panująca polszczyzna"27. Odnosiło się to również do Żydów, którym oprócz narzucenia używania mowy polskiej projektowano zgolić brody i nakazać noszenie takiego samego ubioru, jak ludność chrześcijańska. W zamian za równouprawnienie Żydzi mieli stać się Polakami, a więc płacić taką samą cenę, co ruscy chłopi ze wschodnich kresów Rzeczpospolitej ${ }^{28}$.

Analizując spór Surowieckiego z Potockim w kwestii żydowskiej niewpływający istotnie na rozwój literatury polemicznejej - wyraźnie dostrzec można, że polemiści przede wszystkim użyli jej, by pognębić ideowych rywali oraz uwypuklić zajmowane światopoglądowe pozycje. Problem żydowski, pozornie pierwszoplanowy, stał się poręcznym narzędziem w toczonym sporze.

Ten przybrał na sile w latach 1820-1821. Tym razem pierwszy do ataku przystąpił minister Potocki. W 1820 r. wydał czterotomową powieść Podróż do Ciemnogrodu przez Świstka Krytycznego, w której w zawoalowany sposób ukazywał problemy i zjawiska istniejące w Królestwie Polskim. Przestrzegając przed powrotem „upadłych zabobonów", w powieści przedstawiał państwo, gdzie panował obskurantyzm, zabobon, nadużycia i nędza, cenzura książek, zacofanie cywilizacyjne; gdzie władza była słaba,

26. Zob. J. Gierowski, Na szlakach Rzeczypospolitej w nowożytnej Europie, red. A. K. Link-Lenczowski, Kraków 2008, s. 622-624.

27. J. Tazbir, W pogoni za Europa, Warszawa 1998, s. 160.

28. J. Tazbir, W pogoni..., dz. cyt., s. 165-167.

29. Zob. A. Kwiatkowska, Piórowe wojny. Polemiki literackie polskiego oświecenia, Poznań 2011, s. 19. 
panoszyła się inkwizycja, swawolili możni panowie, Żydzi opanowali miasta i miasteczka, chłopi cierpieli biedę, uciskani przez właścicieli i rozpijani przez żydowskich karczmarzy. Enklawy oświecenia były nieliczne, ale w ostatecznym rozrachunku to one zatriumfowały w kraju. Przewodnikami po tym królestwie Potocki uczynił pielgrzymów z Polski zaproszonych przez władcę Ciemnogrodu, Najciemniejszego Pana, pragnącego zasięgnąć pewnych wiadomości o Sarmacji. Podróżni zaś relacjonowali przebieg swojej wędrówki, m.in. we właściwy dla admiratorów oświecenia sposób ukazali napotkanych kapłanów ${ }^{30}$.

W powieści Potockiego ciemnogrodzkim duchownym daleko było do oświeceniowego wzorca, modelowego księdza - cnotliwego, pracowitego, aktywnego duszpastersko i zaangażowanego społecznie, mającego do spełnienia misję duchową, kulturową i cywilizacyjną ${ }^{31}$, ale minister uspokajał czytelników, że książkowi kapłani nie mieli nic wspólnego ze współczesnymi. Zapewniwszy więc sobie alibi, rozpoczął szturm. W pierwszym rzędzie dostało się ciemnogrodzkim mnichom w powieści określanych bonzami. Autor Podróży do Ciemnogrodu przypisał im zestaw win znanych chociażby z „Monachomachii" Ignacego Krasickiego ${ }^{32}$. Dlatego też furtian w jednym z powieściowych klasztorów, "Był to bonz rumiany i ospały, co sobie już od rana należycie podchmielił". Jego przełożony zaś, witając gości z Polski, kiedy otwarły się podwoje klasztoru „wtoczył się niż wszedł [...] z kilku kapitularnemi, habit wyjąwszy doskonałemi wzorcami Bachusów i Silenów, jakich nam dawne wystawiaja płaskorzeźby. Po głębokich pokłonach i komplemencie przełożonego, w którym tak mu się język plątał, że to tylko zrozumiałem, iż ten klasztor jeden z najuboższych w kraju, nie

30. Zob. [S. K. Potocki], Podróż do Ciemnogrodu przez autora Świstka Krytycznego, cz. I-IV, Warszawa 1820; S. K. Potocki, Podróż..., dz. cyt., s. LXIX-LXXIX.

31. Zob. M. Deszczyńska, "Historia sacra” $i$ dzieje narodowe. Refleksja historyczna lat 1795-183o nad rola religii i Kościoła w przeszłości Polski, Warszawa 2003, s. 107-110; M. Ślusarska, Oświeceniowe modele biskupa, plebana i parafii. Kontynuacja czy zmiana tradycji?, w: Dwór - plebania - rodzina chłopska. Szkice z dziejów wsi polskiej XVII i XVIII wieku, red. M. Ślusarska, Warszawa 1998, s. 37-53.

32. We wstępie Potocki zaznaczał, iż potęga i bogactwo duchowieństwa to przeszłość, podobnie jak rozluźnienie życia mniszego opisanego niegdyś przez bpa Krasickiego w Monachomachii i Antymonachomachii. Zwracał się więc do czytelników Podróży: "O tę łaskę proszę i dla bonzów moich, gdyby się komu, choć przeciwko wszelkiemu podobieństwu uroiło w głowie, że mają coś wspólnego z dzisiejszemi zakonnikami naszemi, których prawdziwie chrześcijańskim cnotom nie omieszkałem w miejscu swojem oddać cześć winną". [S. K. Potocki], Podróż..., dz. cyt., cZ. I, s. VIII. 
był godny tak wielkich jak my gości"33. Nauka w tym klasztorze nie cieszyła się estymą, za to w poważaniu był obfity w jedzenie i picie stół. Mnisi skupiali swoje wysiłki na podtrzymywaniu nadmiernie wystawnego kultu, byli bowiem opiekunami miejsca pielgrzymkowego, gdzie znajdowała się obwieszona złotymi i srebrnymi wotami słynąca łaskami „cudowna Pagoda". Zajmując zaś uprzywilejowaną pozycję w kraju, zakonnicy dbali o to, by ich status nie został naruszony.

Pozostali ciemnogrodzcy duchowni doświadczali rozwarstwienia ekonomicznego, otrzymywali przestarzałą wiedzę, w kwestii celibatu uprawiali hipokryzję, poprzestawali na zewnętrznych formach pobożności, ustawicznie utyskiwali na upadek religijności, zabiegali o realizację własnych karier. Zakonnice natomiast zamieszkiwały miasta. W bogatych klasztorach uprzywilejowane siostry prowadziły wystawne, światowe życie. Te z niższych warstw społecznych zachowywały regułę, stając się "pierwszych niewolnicami, z których każda ma ich przynajmniej po dwie przywiązanych do usługi swojej, z nieograniczoną nad niemi władzą"34. Nad wszystkimi osobami duchownymi górował Wielki Lama, rządca absolutny. Był wyrocznią w sprawach wiary. Urząd swój sprawował dożywotnio. Wyznaczał swego następcę. Zamieszkiwał wystawną rezydencję w Świętogrodzie, która była "nie tylko religii, ale i zalotności siedliskiem, [...] zgoła wśród swojej świętości jest on [Wielki Lama - R. S.] uczniem Epikura, a dwór jego i życie ciemnogrodzkim sposobem, podobne do tego, jakie mówią, że prowadził" 35 .

Lecz nie tylko tacy duchowni znajdowali się w królestwie Najciemniejszego Pana. Potocki dla kontrastu wprowadził do powieści misjonarzy-przybyszów, którzy kierowali się miłością bliźniego i gorliwością w krzewieniu wiary. Gotowi byli poświęcić się Bogu i ludzkości oraz posiadali praktyczne umiejętności, tj. znali się na medycynie ${ }^{36}$. To grono światłych księży zasilił jeszcze proboszcz jednego z polskich pielgrzymów, dołączając w Ciemnogrodzie do swego podopiecznego. W recenzji powieści został zobrazowany w następujący sposób: „Proboszcz najlepszy z ludzi posiada te połączone przymioty gorliwości i łagodności, których każdemu księdzu

33. [S. K. Potocki], Podróż..., dz. cyt., cz. I, s. 94-95.

34. [S. K. Potocki], Podróż..., dz. cyt., cz. II, s. 41.

35. [S. K. Potocki], Podróż..., dz. cyt., cz. IV, s. 44-50.

36. [S. K. Potocki], Podróż..., dz. cyt., cz. II, s. 139-140.

Ks. Rafał Szczurowski, Oświecenie i kontroświecenie... 
życzyć wypada, podług prawdziwego ducha słodkiej wiary naszej"37. Na tak zaś zarysowanym tle autor Podróży do Ciemnogrodu podjął się obrony i wyjaśniania zasad polityki wyznaniowej i oświatowej prowadzonej w Królestwie Polskim.

Za pośrednictwem narratora Potocki przekonywał, iż wszystko, co działo się w Kongresówce w sprawach religii, było dla jej utwierdzenia. Kasaty klasztorów odbyły się za wiedzą zwierzchności duchownej. Przejęte majątki zostały przeznaczone na cele kościelne ${ }^{38}$. Rząd hojnie uposażył biskupów. Ci byli wybierani ze względu na ich zasługi i wartość. Zakonnikom władze Królestwa otworzyły drogę do zaszczytów. Nie wzbraniały im prowadzenia działalności edukacyjnej, choć nie ona było ich powołaniem i mieli braki w przygotowaniu merytorycznym. Nadto cały system szkolnictwa sprzyjał religijnemu kształceniu i dawał duchowieństwu możliwości wpływu na postawy uczniów - „gdyby rzecz się tak nie miała, niech nie zwraca na kogo innego własnej w tem opieszałości"39. Odnośnie do inkwizycji to, jak zauważał minister Potocki, w Polsce dzięki mądrości przodków takowa nie działała. Zaprzeczeniem tej mądrości byłaby próba wskrzeszenia inkwizycji na wzór Hiszpanii czy niektórych innych państw ${ }^{40}$.

Powyższa argumentacja, a z nią cała kreacja powieściowa ministra-literata nie zdobyła jednak szerszego uznania. Recepcja Podróży do Ciemnogrodu okazała się nikła. Jej typowe dla XVIII w. ujęcie nie przemawiało do publiczności. Dzieło odstraszało swoją długością, trudną do zrozumienia treścią, wymagającą zarówno znajomości przeszłości, jak i zagadnień bieżących ${ }^{41}$. Pomimo tego o. Surowiecki nie omieszkał zareagować na utwór Potockiego.

W 1821 r. reformat opublikował polemiczną broszurę Świstak warszawski wyświstany czyli uwagi krytyczne nad warszawskim romansem tytułowanym: "Podróż do Ciemnogrodu". Pod imieniem pisarza nazwanego Świstek

37. Recenzya. "Podróż do Ciemnogrodu przez Świstka Krytycznego", [b. m. r.], s. 17.

38. Za zgodą papieską w 1819 r. w Królestwie Polskim dokonano zniesienia części klasztorów. Zlikwidowano ich jednak więcej, niż dopuszczał Rzym. Bulla papieska z 1820 r. nakazywała naprawić nadużycie. Ostatecznie dekretem z 16 VIII 1822 dochody skasowanych placówek przejęto na poczet funduszu religijnego. Zob. M. Deszczyńska, Biskup Wojciech Skarszewski a dymisja Stanisława Kostki Potockiego, "Kwartalnik Historyczny" 106 (1999) z. 1, s. 54.

39. [S. K. Potocki], Podróż..., dz. cyt., cz. II, s. 119-135.

40. [S. K. Potocki], Podróż..., dz. cyt., cz. II, s. 128.

41. Zob. S. K. Potocki, Podróż..., dz. cyt., s. XC. 
przez drukarska pomyłkę. Już w samum tytule ośmieszał adwersarza. Przekręcił jego pseudonim - Świstka zmienił na Świstaka. Informował przy tym, iż naprawił tylko błąd drukarski, którego w rzeczywistości nie było. Na kolejnych stronicach swojego pisma zarzucał oponentowi kłamstwo, szalbierstwo, przewrotność. Sięgnął także, jak to miał w zwyczaju, po niewybredne epitety. Potockiego nazywał grymolarzem, liberalnym półgłówkiem, warszawskim pierdołą, Wielkim Mistrzem liberalnych pierdołów, wyuzdańcem ${ }^{42}$. Za napaść na Maryję w jasnogórskim wizerunku (cudowna Pagoda) wykluczał autora Podróży do Ciemnogrodu z grona nie tylko czcicieli Bożej Rodzicielki, ale i ze wspólnoty narodowej. Przeciw Potockiemu stanął w obronie zakonów grabionych i upadających w Królestwie Polskim, nękanych przez „liberalistów", zagrożonych liberalną oświatą ${ }^{43}$. Sprzeciwiał się uogólniającej krytyce duchowieństwa. Bronił egzorcyzmów i obstawał przy wierze w czary oraz istnienie czarownic, zapowiadając, iż „upadnie dzisiejsza bydlęca filozofia, zginą bezbożne archaicznych wyuzdańców projekta i antychrystiańskie królestwo, którego organizacyi nasi kosmopolitowie, reformatorowie, budowniczy świata już blisko dosięgaja końca, skoro weźmie zupełną nad królestwem Chrystusowym przewagę, wnet wszechmocną tegoż Boga Zbawiciela prawicą zniszczone zostanie"44. O. Surowiecki w Świstaku warszawskim tłumaczył także historię inkwizycji kościelnej, jej rolę, wymiar społeczny oraz przedstawiał prawdziwie bezkrwawe oblicze. Uderzał za to w nowa filozofię rozumianą jako oświatę źródło rewolucji, kłamstwa, powierzchowności. Prognozował przy tym: "Jeżeli się poszykuje dzisiejszym liberalistom w naszych siedliskach tak upowszechnić i wygórować oświatę, jak przed lat kilkadziesiąt we Francyi,

42. Surowiecki często obwiniał swoich przeciwników o kłamstwo, herezję, bluźnierstwo, przynależność do masonerii. Z wolnomularzy czynił postaci diaboliczne, wrogów katolicyzmu, bezbożników, budowniczych antychrześcijańskiego królestwa, przeciwników władzy państwowej, sekciarzy-manichejczyków, zob. S. Małachowski-Łempicki, Ksiądz Surowiecki w walce z wolnomularstwem, „Przegląd Powszechny" 48 (1931) nr 190, s. 95-101. Niejednokrotnie atakował autorów, z których utworami polemizował. Zob. A. Kwiatkowska, Piórowe..., dz. cyt., s. 115-116.

43. W odpowiedzi udzielonej Potockiemu zakonnik-polemista ukazywał klasztory jako siedliska mądrości ewangelicznej, pracy zgodnej z powołaniem, osiągania chrześcijańskiej dojrzałości, istniejące dzięki ofiarności świeckich. Zob. [K. Surowiecki], Świstak warszawski wyświstany czyli uwagi krytyczne nad warszawskim romansem tytułowanym: "Podróż do Ciemnogrodu". Pod imieniem pisarza nazwanego Świstek przez drukarska pomyłkę, [Łowicz lub Warszawa] 1821, s. 45-56.

44. [K. Surowiecki], Świstak..., dz. cyt., s. 72.

Ks. Rafał Szczurowski, Oświecenie i kontroświecenie... 
gotowem łożyć życie, że do tego samego stopnia wzniesie się u nas nędza, na którym ją tameczni jakobini stawili"45.

Prognoza ta, jak i cała krytyka Surowieckiego, nie znalazła jednak poparcia u zwierzchności duchownej Królestwa Polskiego. Wręcz przeciwnie. Zakonnik, upomniany już po opublikowaniu Głosu narodu izraelskiego za wtrącanie się do polityki, po wydaniu Świstaka warszawskiego, kiedy ministra Potockiego nie było już wśród żywych, ukarany został przez abpa Szczepana Hołowczyca. Hierarcha, obawiając się zatargu z opiniotwórczymi elitami Królestwa, zawiesił czasowo polemistę w czynnościach kapłańskich, nakazał wycofanie broszury z handlu i przeniósł Surowieckiego do klasztoru w Miedniewicach. Tam też reformat zmarł 26 kwietnia 1824 r. i został pochowany w podziemiach kościoła klasztornego ${ }^{46}$.

Stanisław Kostka Potocki rozstał się z tym światem prędzej niż o. Surowiecki, zmarł 14 września 1821 r. Kilka miesięcy wcześniej został odwołany przez Aleksandra I ze stanowiska ministra wyznań religijnych i oświecenia publicznego. Inspirowani przez Mikołaja Nowosilcowa biskupi - Jan Paweł Woronicz, Wojciech Skarszewski, Ignacy Czyżewski przedłożyli monarsze memoriał piętnujący Komisję Rządową Wyznań Religijnych i Oświecenia Publicznego i jej kierownika za politykę wobec duchowieństwa. Na potwierdzenie Woronicz przekazał imperatorowi egzemplarz Podróży do Ciemnogrodu. Ten 9 grudnia 1820 r. podpisał dymisję ministra-literata ${ }^{47}$. Potocki usunął się do Wilanowa, gdzie dokończył żywota i gdzie został pochowany. Na pogrzeb przybyły liczne rzesze, a wśród nich duchowni i wolnomularze. Jedni i drudzy mieli powody do złożenia pośmiertnej czci zmarłemu. Za życia Potocki przewodził masonom, co nie przeszkadzało mu z sympatią odnosić się do pijarów, szczególną troską otaczał konwent warszawskich bernardynów, a wymagając od zakonów włączenia się w ład kościelny Królestwa Kongresowego, zapewnił im rządową opie$\mathrm{kę}^{48}$. Młodzież również miała pobudki do uhonorowania ministra za wkład w rozwój oświaty. Wyraziła to niosąc trumnę zmarłego. U potomnych zaś

45. [K. Surowiecki], Świstak..., dz. cyt., s. 141.

46. Zob. A. J. Szteinke, Surowiecki... (PSB), dz. cyt., s. 11-12; M. Deszczyńska, Styl..., dz. cyt., s. 476-477; E. Jabłońska-Deptuła, Przystosowanie i opór. Zakony męskie w Królestwie Kongresowym, Warszawa 1983, s. 23.

47. Zob. B. Grochulska, Potocki..., dz. cyt., s. 168; A. Winiarz, Szkolnictwo..., dz. cyt., s. $38-40$.

48. Zob. E. Jabłońska-Deptuła, Przystosowanie..., dz. cyt., s. 37, 48. 
przetrwała pamięć o człowieku, który potrafił dojrzeć i docenić zalety swojego ideowego przeciwnika, Karola Surowieckiego. Zachował się przekaz, że po spotkaniu z zakonnikiem, „zbadawszy, iż to był człowiek przekonania i czynu, lubo różniący się od niego opiniami, wiele odtąd powziął dla niego szacunku"49.

Śmierć Stanisława Kostki Potockiego była na wskroś symboliczna. Odchodził przedstawiciel pokolenia uformowanego przez epokę rozumu, która sama chyliła się ku końcowi. Nadchodziło nowe, rewidujące oświeceniowe wizje, w tym te odnoszące się do Kościoła. Ten zaś w warunkach rozbiorowych będzie pełnił ważną funkcję - nosiciela narodowej tradycji. Tego minister Potocki nie przewidział, podobnie jak tego, że w Kongresówce prym wezmą nowe tendencje, sprzyjające m.in. ożywieniu życia religijnego. O. Karol Surowiecki, choć zza grobu, mógł poczuć się zwycięzca, za co jego formacji ideowej przyszło jednak płacić lojalizmem wobec władz politycznych, uwikłaniem w utwierdzanie porządku zaprowadzonego po kongresie wiedeńskim.

W opozycji do tej postawy przebiegał proces wolnościowego postrzegania roli religii i Kościoła w życiu narodu polskiego, uzewnętrzniony w powstaniu listopadowym. Kolejne pokolenia przedłużą ten proces, spierając się w zmieniających się okolicznościach politycznych i klimacie kulturowym o kształt polskiego Kościoła. Przyczynią się tym samym do rozwoju rodzimej wspólnoty wierzących w Chrystusa.

49. E. Skrodzki, Wielisław, Wieczory piatkowe $i$ inne gawędy, oprac. i wstęp M. Opałek, Warszawa 1962, s. 24-25.

Ks. Rafał Szczurowski, Oświecenie i kontroświecenie... 


\section{Bibliografia}

Źródła

Diariusz Sejmu Królestwa Polskiego 1818, t. 3, Warszawa [b. r.].

S. K. [Potocki], Podróż do Ciemnogrodu przez autora Świstka Krytycznego, CZ. I-IV, Warszawa 1820.

S. K. Potocki, Podróż do Ciemnogrodu i Świstek Krytyczny, oprac. E. Kipa, Wrocław 1955.

[S. K. Potocki], Żyd nie Żyd? Odpowiedź na głos ludu izraelskiego, [b. m. r.]. Recenzya. "Podróż do Ciemnogrodu przez Świstka Krytycznego", [b. m. r.].

E. Skrodzki, Wielisław, Wieczory piątkowe i inne gawędy, oprac. i wstęp

M. Opałek, Warszawa 1962.

[K. Surowiecki], Głos ludu izraelskiego do prawdziwych chrześcijan polskich, przeciw fałszywym ich politykom, z okazyi projektów ku zgubie tegoż ludu rozrzuconych między stany sejmujace w Warszawie. Przez Rabbi ben Abrahama duchownego synagogi Ł. R. Ery chrześcijańskiej 1818, [b. m. r.].

[K. Surowiecki], Świstak warszawski wyświstany czyli uwagi krytyczne nad warszawskim romansem tytułowanym: "Podróż do Ciemnogrodu”. Pod imieniem pisarza nazwanego Świstek przez drukarska pomyłke, [Łowicz lub Warszawa] 1821.

\section{Opracowania}

R. Butterwick, Between Anti-Enlightenment and enlightened Catholicism: provincial preachers in late eighteenth-century Poland-Lithuania, w: Perepheries of the Enlightenment, ed. R. Butterwick, S. Davis, G. Sanchez Espinoza, Oxford 2008, s. 201-208 (Studies on Voltaire and the Eighteenth Century, 1).

R. Butterwick, Co to jest oświecenie?, "Przegląd Powszechny" 921 (1998) nr 5, s. $161-180$.

R. Butterwick, Polska rewolucja a Kościół katolicki 1788-1792, Kraków 2012. 
T. Cegielski, Jansenizm i gallikanizm w polskim Oświeceniu. Badaniaopinie - postulaty, w: W stronę Francji... Z problemów literatury i kultury polskiego Oświecenia, red. E. Z. Wichrowska, Warszawa 2007.

M. Deszczyńska, Biskup Wojciech Skarszewski a dymisja Stanisława Kostki Potockiego, "Kwartalnik Historyczny” 106 (1999) z. 1, s. 45-56.

M. Deszczyńska, "Historia sacra” i dzieje narodowe. Refleksja historyczna lat 1795-183o nad rola religii i Kościoła w przeszłości Polski, Warszawa 2003.

M. Deszczyńska, Polskie kontroświecenie, Warszawa 2011.

M. Deszczyńska, Styl, gust, realia. O publicystyce ks. Karola Surowieckiego, w: Non cesso gratias agere Deo et hominibus. Prace ofiarowane Ojcu dr. Anzelmowi Januszowi Szteinke OFM z okazji Złotego Jubileuszu Kapłaństwa i ponad 5o-lecia pracy historyczno-pisarskiej, red. W. M. Michalczyk, C. M. Pankowski, Kraków-Warszawa 2013, s. 467-484.

J. Gierowski, Na szlakach Rzeczypospolitej w nowożytnej Europie, red. A. K. Link-Lenczowski, Kraków 2008.

B. Grochulska, Potocki Stanisław Kostka, w: Polski Słownik Biograficzny, t. 28, Wrocław-Warszawa-Kraków-Gdańsk-Łódź 1984-1985, S. $158-170$.

B. Grochulska, Dramat liberała, w: Losy Polaków w XIX-XX w. Studia ofiarowane Profesorowi Stefanowi Kieniewiczowi w osiemdziesiata rocznice Jego urodzin, red. B, Grochulska, J. Skowronek, Warszawa 1987, s. $137-149$.

L. Hass, Sekta farmazonii warszawskiej. Pierwsze stulecie wolnomularstwa w Warszawie (1721-1821), Warszawa 1980.

E. Jabłońska-Deptuła, Przystosowanie i opór. Zakony męskie w Królestwie Kongresowym, Warszawa 1983.

S. Janeczek, Oświecenie chrześcijańskie. Z dziejów polskiej kultury filozoficznej, Lublin 1994.

K. Karaskiewicz, Wpływ idei niemieckiego oświecenia na edukacyjna działalność prymasa Michała Poniatowskiego. Fascynacje i kontakty, "Mazowieckie Studia Humanistyczne" 5 (1999) nr 1, s. 67-91.

T. Kostkiewiczowa, Polski wiek świateł. Obszary swoistości, Wrocław 2002.

J. Kracik, Ewangelicznie i rozumnie. Oświecenie katolickie, "Znak" 44 (1992) nr 451, s. 57-69. 
A. Kwiatkowska, Piórowe wojny. Polemiki literackie polskiego oświecenia, Poznań 2011.

S. Małachowski-Łempicki, Ksiadz Surowiecki w walce z wolnomularstwem, "Przegląd Powszechny" 48 (1931) nr 190, s. 95-101.

M. Nowodworski, Ksiadz Karol Surowiecki, Warszawa 1870.

G. Schweiger, Oświecenie a katolicyzm, "Concilium" 1966-1967, s. 73-82.

M. Skrzypek, Józefinizm w polskim oświeceniu, "Przegląd Humanistyczny" 38 (1994) z. 2, s. 41-56.

W. Smoleński, Przewrót umysłowy w Polsce wieku XVIII. Studia historyczne, oprac. i wstęp A. Wierzbicki, Warszawa 1979.

J. Snopek, Objawienie i Oświecenie. Z dziejów libertynizmu w Polsce, Wrocław 1986.

J. Snopek, Oświecenie. Szkice do portretu epoki, Warszawa 1999.

R. Szczurowski, "Zaradzić potrzebom doczesnym $i$ wiecznym”. Idee oświecenia w Kościele katolickim w Polsce (do 1795 r.), Kraków 2014.

A. J. Szteinke, Kościół świętego Antoniego i klasztor Franciszkanów-Reformatów w Warszawie 1623-1987, Kraków 1990.

A. J. Szteinke, Surowiecki Karol, w: Polski Słownik Biograficzny, t. 46, Warszawa-Kraków 2009-2010, s. 9-12.

A. J. Szteinke, Surowiecki Karol, w: Słownik Polskich Teologów Katolickich, red. H. E. Wyczawski, t. 4, Warszawa 1983, s. 226-228.

M. Ślusarska, Oświeceniowe modele biskupa, plebana i parafii.

Kontynuacja czy zmiana tradycji?, w: Dwór - plebania - rodzina chłopska. Szkice z dziejów wsi polskiej XVII i XVIII wieku, red. M. Ślusarska, Warszawa 1998, s. 37-53.

J. Tazbir, W pogoni za Europa, Warszawa 1998.

F. Valjavec, Geschichte der abendländischen Aufklärung, Wien-München 1961.

A. Winiarz, Szkolnictwo Księstwa Warszawskiego i Królestwa Polskiego (1807-1831), Lublin 2002.

W. Woźniakowski, Pamflet obyczajowy w czasach Stanisława Augusta, Wrocław-Warszawa-Kraków-Gdańsk 1973. 


\section{Abstract}

Ks. Rafał Szczurowski

The Enlightenment and Counter-Enlightenment in the age

of the Kingdom of Poland. The polemics between

Father Karol Surowiecki and minister Stanisław Kostka Potocki

By criticizing the world around them, the supporters of the idea of Enlightenment brought about profound transformations in all areas of life. This did not mean, however, that such ideas and transformations gained widespread acceptance. On the contrary, their opponents, who saw decline and demoralization in lieu of 'enlightenment', developed the Counter-Enlightenment movement. Critically perceiving modernity, they asked questions about the arbitrariness of human reason, the concept of human nature and human morality, giving answers from the position of Christian apologists. Therefore in the period of the Kingdom of Poland, the Polish anti-Enlightenment movement persevered against eighteenth-century philosophy, opposing everything they considered harmful to modernity and religion.

A perfect example of the struggle between representatives of hostile ideological factions was the polemics between Father Karol Surowiecki and Stanisław Kostka Potocki, minister of the Kingdom. Educated in the age of reason and following the assumptions of the Enlightenment, the minister was a symbol of the rational changes in the Second Polish Republic in the second half of the 18th century. On the other side of the barricade stood Father Surowiecki, an anti-Enlightenment Franciscan reformer, fiercely defending the Church and religion. Their clash perfectly illustrated the incompatibility of their intellectual worlds.
Keywords:

Enlightenment, CounterEnlightenment, polemics, Karol Surowiecki, Stanisław Kostka Potocki. 


\section{Abstrakt}

Ks. Rafał Szczurowski

Oświecenie i kontroświecenie czasów Królestwa Polskiego. Polemika o. Karola

Surowieckiego z ministrem Stanisławem Kostka Potockim

Słowa kluczowe: oświecenie, kontroświecenie, polemika, Karol Surowiecki, Stanisław Kostka Potocki.
Zwolennicy idei oświecenia, poddając racjonalnej krytyce otaczającą ich rzeczywistość, dokonali gruntownych przeobrażeń we wszystkich dziedzinach życia. Nie oznaczało to jednak, że owe idee i przeobrażenia zyskały powszechną akceptację. Ich przeciwnicy, rozwijając nurt kontroświecenia, zamiast oświeceniowego postępu dostrzegali głęboki upadek i demoralizację. Krytycznie postrzegając nowoczesność, pytali o arbitralność rozumu ludzkiego, o koncepcję natury człowieka, o jego moralność, odpowiedzi udzielając z pozycji apologetów chrześcijaństwa. Dlatego też w dobie Królestwa Polskiego rodzimi antyoświeceniowcy wytrwale zwalczali osiemnastowieczną filozofię, występując przeciwko temu wszystkiemu, co uznali za szkodliwe dla współczesności i religii.

Modelowym wręcz przykładem zmagań reprezentantów przeciwstawnych formacji ideowych była polemika o. Karola Surowieckiego z ministrem Stanisławem Kostką Potockim. Ukształtowany w epoce racjonalizmu i działający według założeń oświecenia minister był symbolem rozumowych przemian w Rzeczpospolitej drugiej połowy XVIII w. Po drugiej stronie światopoglądowej barykady stał o. Surowiecki, antyoświeceniowo nastawiony franciszkanin-reformat, który zaciekle bronił Kościoła i religii. Ich polemiczne starcie doskonale obrazowało, jak bardzo prezentowane przez nich myślowe światy nie przystawały do siebie. 